\title{
Influence on the NIHL of Miners with Age, Sex, and Work Period
}

\author{
Yanti Nurrokhmawati* \\ Department of THTKL \\ Universitas Jenderal Achmad Yani \\ Cimahi, Indonesia \\ *yantinurrokhmawati@gmail.com \\ Irwanto Ichlas \\ Department of Psikiatri \\ Universitas Jenderal Achmad Yani \\ Cimahi, Indonesia
}

\author{
Leni Herlina \\ Medical Faculty \\ Universitas Jenderal Achmad Yani \\ Cimahi, Indonesia
}

\author{
Siti Endah Virajati Buana \\ Medical Faculty \\ Universitas Jenderal Achmad Yani \\ Cimahi, Indonesia
}

\begin{abstract}
Noise-Induced Hearing Loss (NIHL) was a serious problem caused by the extremely loud sound in the working place. According to the Occupational Health and Safety Administration (OSHA), 22 billion workers in the United States are exposed to NIHL because they are exposed to loud noise at work. This study aims to determine the relationship between age, sex, and the duration of the work to NIHL of miners at PT. Window Andesit Utama (PT. WAU). The method was crosssectional analytic. Primary data collected from a questionnaire, otoscopic, and audiometric exam. Eighty-six miners of the subject taken with simple random sampling. The data were analysed univariately, using a chi-square test. The chi-square test result was tested with Wald Test to determine the effect of the variable. The result showed that 33 workers had NIHL $(38,37 \%), 17$ workers $(51,52 \%)$ were under 40 years old, all $100 \%$ were men, and 19 workers $(57,58 \%)$ worked no longer than 5 years. The number of NIHL case showed a significant score statistically with age $(p=0,022, P R=1,850)$ and duration of the work $(p=0,031$, $P R=1,798$ ). Wald's tests showed that there was not free variable that had an effect on the NIHL.
\end{abstract}

Keywords—noise, noise induced hearing loss, miners

\section{INTRODUCTION}

Noise-Induced Hearing Loss (NIHL) was hearing loss caused by prolonged exposure to noise. It is characterized as sensorineural hearing loss and is usually bilateral, irreversible, and progressive while the exposure to noise continues [1]. World Health Organization (WHO) in 2012 there are three hundred and sixty million people in the world suffering from hearing loss $(5,3 \%$ of the world's population), there were three hundred and eighty million (91\%) adult, one hundred eightythree million men, one hundred forty-five million women, thirty-two million (9\%) child [2]. Based on Occupational Health and Safety Administration (OSHA), twenty-two million workers in America who were exposed by noise continue $>85$
dB had a risk of NIHL. Research in Lanud Husein Sastranegara West Java by thirty-three participants who were exposed to noise $>85 \mathrm{~dB}$ showed the incidence of NIHL were 11 participants $(78,6 \%)$ with a work period $>5$ years and 9 participants $(47 \%)$ with a work period $<5$ years [3].

Noise-induced hearing loss (NIHL) is a worldwide occupational health risk, one of them was mining. PT. Windoe Andesit Utama was a company in the andesite rock mining sector. There were two kinds of noise in this company, namely impulsive and continue. The impulsive noise comes from blasting process once a week, while continue noise comes from primary crushing and secondary crushing produces fluctuating noise in the open space with high intensity was $88-118 \mathrm{~dB}$. The generator works for 14 hours per day, miners exposed the noise 7 hours per day with a distance was $1 \mathrm{~km}$. According to Peraturan Menteri Tenaga Kerja dan Transmigrasi Republik Indonesia nomor per.13/MEN/X/2011 about threshold noise value at work that does not exceed $85 \mathrm{~dB}$ in 8 hours [4].

Based on WHO at the age $>40$ years old, the risk of hearing loss increasing to $4,3 \%,>50$ years old increasing to $7,9 \%$, and $>60$ years old increasing to $9,6 \%[2,5]$. Process degenerative began at 40 years old that reducing the function of cells, innervation, and supply of blood to the cochlea [6-8]. The incidence NIHL of men more than women presumably because in mining industry dominated by men [9].

Noise in the mining company that exceeds the hearing threshold value was a problem that has not realized by miners or that company because the patient with NIHL did not show significant complaints. This was an impact that increased the risk of hearing loss to severe and irreversible. The risk was exacerbated by the age, gender, and work period. 
There was no research on the incidence of NIHL in the miner's sector in west java, so this study aims to find out the association between age, sex, and the duration of work to NIHL of miners at PT. Windoe Andesit Utama (PT. WAU).

\section{METHODS}

The method of this research was an analytic method by using a cross-sectional design. The subjects of the research were all miners at PT. Windoe Andesit Utama who appropriate with inclusion criteria. There were miner's who exposed the noise $>85 \mathrm{~dB}$, working $>4$ hours per day, and willing to be the subject of research. The exclusion criteria were history of taking an ototoxic drug, tympanic membrane rupture, history of otore, congenital hearing loss, age $>65$ years old, history of acoustic tumor, history of head and neck injury, and conductive hearing loss.

Sampling was done by simple random sampling. Minimal sample with two proportion hypothesis were 38 samples for each group. Research subjects conducted a guided interview with a questionnaire and then physical examination with otoscopy, if the subjects appropriate with inclusion criteria then to audiometric examination. The independent variable was age, gender, and work period. The dependent variable was type of hearing loss. Data were analyzed by univariate to determine the frequency, bivariate analyzed with chi-square to determine the relationship between the independent and dependent variable, and multivariate analyzed with Wald test to determine the effect of independent variable on dependent variable.

\section{RESULTS AND DISCUSSION}

The research was conducted at PT. Windoe Andesit Utama, Kabupaten Bogor with 86 respondents who entered the inclusion criteria. Characteristics were age, gender, work period, and type of hearing loss. The youngest age was 18th years old and the oldest was 58th years old. Miners < 40 years old $(66,28 \%)$ more than $\geq 40$ years old $(33,72 \%)$ because the productive age was $<40$ years old. The workers dominated by men $(96,51 \%)$ while women $(3,49 \%)$. Work period $<5$ years $(71,93 \%)$ more than $>5$ years $(29,07 \%)$. In the last 3 years the requirement of workers more frequent than before because many workers had resigned. The workers with $>5$ years had a certain contract with the company. In this research, the result who diagnosed NIHL was 33 participants $(38,37 \%)$ less than non-NIHL 53 participants $(61,63 \%)$. The category of nonNIHL was normal hearing function, sensorineural hearing loss without a notch at $4000 \mathrm{~Hz}$, conductive hearing loss, and mix. 19 participants $(22 \%)$ were normal hearing functions. Many possibilities can cause a high incidence of hearing loss in mining one of them was many workers do not use ear protection/earplugs, several workers just cover their ears with cotton. Workers who use PPE were only the expert such as generator operators, electrical, and blasting process.

\section{A. Analysis between Age and Type of Hearing Loss}

Bivariate analysis using chi-square stated there was a statically significant relationship between age with NIHL with $\mathrm{p}$-value $=0,022(\mathrm{p}<0,05)$ (Table 1). Process degenerative began at 40 years old that reducing the function of cells, innervation, and supply of blood to the cochlea. This process can be compounded by noise exposure, chronic ear infection, and genetics $[2,6,8]$.

This research corresponding with Septiana and Widowati [6] regarding factors related to NIHL in PT. Indonesia Power UBP Semarang showed a significant relationship between age and NIHL with a p-value 0,036 , OR 2,429 which means the workers $>40$ years old had a risk of 2,429 times than workers $<40$ years old

TABLE I. BIVARIATE ANALYSIS BETWEEN AGE AND TyPE OF HEARING LOSS

\begin{tabular}{|l|c|c|c|c|c|c|c|}
\hline \multirow{2}{*}{ Age } & \multicolumn{4}{|c|}{ Type of hearing loss } & \multirow{2}{*}{$\mathbf{X}^{2}$} & \multirow{2}{*}{ P } & \multirow{2}{*}{ PR } \\
\cline { 2 - 5 } & \multicolumn{2}{|c|}{ NIHL } & \multicolumn{2}{c|}{ Non-NIHL } & & & \\
\cline { 2 - 5 } & $\boldsymbol{f}$ & $\boldsymbol{\%}$ & $\boldsymbol{f}$ & $\boldsymbol{\%}$ & & & \\
\hline$>40$ yo & 16 & 48,48 & 13 & 24,53 & 5,222 & 0,222 & 1,850 \\
\hline$<40$ yo & 17 & 51,52 & 40 & 75,47 & & & \\
\hline Total & 33 & 100 & 53 & 53 & & & \\
\hline
\end{tabular}

\section{B. Analysis between Gender and Type of Hearing Loss}

Bivariate analysis using chi-square stated there was no significant relationship between gender with NIHL with $p$ value $=0,022 \quad(\mathrm{p}>0,05)$. There was no different anatomy between man and woman. According to a study conducted by Fathonah in Anthropology of Gadjah Mada University, miners was an industry with a masculine character that was only suitable by men so the mining industry more dominated by men [10].

The result of this study corresponding with Siregar et al., in South Kalimantan has not had a relationship between gender and NIHL [11].

Based on table 2, women who work in PT.WAU was not NIHL presumably because there work in the personnel section so that the exposure was less than another.

TABLE II. BIVARIATE ANALYSIS BETWEEN GENDER AND TYPE OF HEARING LOSS

\begin{tabular}{|l|l|l|l|l|l|l|}
\hline \multirow{2}{*}{ Gender } & \multicolumn{4}{|c|}{ Type of hearing loss } & \multirow{2}{*}{$\mathbf{X}^{\mathbf{2}}$} & \multirow{2}{*}{ P } \\
\cline { 2 - 5 } & \multicolumn{2}{|c|}{ NIHL } & \multicolumn{2}{c|}{ Non-NIHL } & \multirow{2}{*}{$\boldsymbol{~}$} & \\
\cline { 2 - 5 } & $\boldsymbol{f}$ & $\boldsymbol{f}$ & $\mathbf{f}$ & & \\
\hline Men & 33 & 100 & 50 & 94,34 & 1,953 & 0,164 \\
\hline Women & 0 & 0 & 3 & 5,66 & & \\
\hline Total & 33 & 100 & 53 & 100 & & \\
\hline
\end{tabular}

\section{Bivariate Analysis between Work Period and Type of Hearing Loss}

The result of chi-square with $\mathrm{p}$-value $=0,031<0,05$ there was a significant relationship between a work period and NIHL. That was following the theory stated continuously noise 
exposure can cause organon corti damage, first temporary threshold shift until permanent threshold shifts less than 5 years [1,12-14]. This study in line with Asrun et al., in PT Antam 2021 that had a significant relationship between work period > 5 years and NIHL (Table 3 ) [15].

TABLE III. BIVARIATE ANALYSIS BETWEEN WORK PERIOD AND TYPE OF HEARING LOSS

\begin{tabular}{|l|c|c|c|c|c|c|c|}
\hline \multirow{2}{*}{ Work Period } & \multicolumn{3}{|c|}{ Type of hearing loss } & \multirow{2}{*}{$\mathbf{X}^{2}$} & \multirow{2}{*}{ P } & \multirow{2}{*}{ PR } \\
\cline { 2 - 5 } & \multicolumn{2}{|c|}{ NIHL } & \multicolumn{2}{|c|}{ Non-NIHL } & & & \\
\cline { 2 - 5 } & $\boldsymbol{f}$ & $\boldsymbol{\%}$ & $\boldsymbol{f}$ & $\mathbf{\%}$ & & & \\
\hline$>$ 5 years & 14 & 42,42 & 11 & 20,75 & 4,631 & 0,031 & 1,798 \\
\hline < 5 years & 19 & 57,58 & 42 & 79.25 & & & \\
\hline Total & 33 & 100 & 53 & 100 & & & \\
\hline
\end{tabular}

\section{Influence Age, Grnder, Work Period of NIHL}

The result of the bivariate analysis was a variable that affects the occurrence of NIHL in PT. Windoe Andesit Utama was age and work period. Multivariate analysis with Wald test stated that $p$-value $>0,005$ that none of the three variables affected NIHL (Table 4).

According to Siregar et al., gender was not influenced by NIHL but the age and work period had an influenced with a $\mathrm{p}$ value $<0,005$ [11].

TABLE IV. INFLUENCE Age, GRNDER, WORK PERIOD OF NIHL

\begin{tabular}{|c|c|c|c|c|c|}
\hline \multirow{2}{*}{$\begin{array}{c}\text { Independent } \\
\text { Variable }\end{array}$} & \multirow[b]{2}{*}{$\begin{array}{l}\text { Wald } \\
\text { Test }\end{array}$} & \multirow[b]{2}{*}{ p-value } & \multirow[b]{2}{*}{ OR } & \multicolumn{2}{|c|}{ IK 95\% } \\
\hline & & & & $\begin{array}{l}\text { Upper } \\
\text { Limit }\end{array}$ & $\begin{array}{c}\text { Lower } \\
\text { Limit }\end{array}$ \\
\hline Age & 2,3335 & 0,127 & 2,157 & 0,805 & 5,782 \\
\hline Gender & 0,000 & 0,999 & & 0,000 & \\
\hline Work Period & 1,840 & 0,1759 & 2,020 & 0,730 & 5,639 \\
\hline
\end{tabular}

\section{CONCLUSION}

The general characteristic of miners at PT. Windoe Andesit Utama were $<40$ years old, male, work period was $<5$ years, and non-NIHL. There wasn't influence of age on NIHL. There wasn't influence of gender on NIHL. There wasn't influence of work period on NIHL.

\section{REFERENCES}

[1] E.A. Soepardi, E.A. Iskandar, J. Bashiruddin, and R.D. Restuti, Telinga hidung tenggorokan kepala \& leher. Edisi ke-7. Jakarta: Badan Penerbit Fakultas Kedokteran Universitas Indonesia, 2012, pp. 42-45.
[2] World Health Organization, Global estimates on prevalence of hearing loss. Geneva: WHO, 2012.

[3] M.F.D. Udyani, Hubungan faktor resiko dengan jenis gangguan dengar pada personil TNI-AU di landasan udara Husein Sastranegara Bandung. Cimahi: Fakultas Kedokteran Universitas Jenderal Ahmad Yani, 2016.

[4] Kementerian Tenaga Kerja dan Transmigrasi, Peraturan Menteri Tenaga Kerja dan Transmigrasi Republik Indonesia Nomor Per.13/MEN/X/2011 tentang: nilai ambang batas faktor fisika dan faktor kimia di tempat kerja. Jakarta: KEMENAKERTRANS, 2011.

[5] J. Ballenger, Penyakit telinga hidung tenggorokan kepala dan leher. Jakarta: Binarupa Aksara, 1997, p. 101-331.

[6] N.R. Septiana and E. Widowati, "Gangguan pendengaran akibat bising," Higeia, vol. 1, pp. 73-82, 2017.

[7] A.F. Ismail, A. Daud, Z. Ismail, and B. Abdullah, "Noise induced hearing loss among quarry workers in a north-eastern state of Malaysia: A study on knowledge, attitude and practice," Oman Medical Journal, vol. 28, pp. 331-336, 2013.

[8] C.K. Gyamfi, I. Amankwaa, F. Sekyere, and D. Boateng, "Noise exposure and hearing capabilities of quarry worker in Ghana: A crosssectional study," Hindawi, vol. 16, pp. 1-7, 2016.

[9] N.J. Mathur, P.S. Roland, and A.D. Meyers, Noise induced hearing loss, 2016. [Online] Retrieved from: http://emedicine.medscape.com/article/857813-overview\#a6.

[10] S. Fathonah, Perempuan dalam industri tambang: telaah antropologis resistensi perempuan terhadap tambang pasir besi di Desa Glempangpasir, Kecamatan Adipala, Kabupaten Cilacap Jawa Tengah. Yogyakarta: Program Pasca Sarjana Ilmu Antropologi Universitas Gadjah Mada, 2015.

[11] A. Siregar, T. Suwandi, and A. Martini, "Analysis of factors affecting to hearing condition of blacksmith workers in Sungai Pinang Village, district of Daha Selatan, South Kalimantan," IJSR, vol. 4, pp. 556-562, 2016.

[12] J.T. Johnson and C.A. Rosen CA, Bailey's head \& neck surgery otolaryngology. 4th ed. China: Lippincott Williams \& Wilkins, 2014. p. 2530-2541.

[13] S. Sasongko, Pengaruh glutation peroksidase mimetik peroral terhadap kadar glutation peroksidase dan malondialdehid darah serta nilai emisi otoakustik pada prajurit dengan risiko trauma akustik akibat ledakan Meriam Howitzer 105. Bandung: Program Studi Doktor Pascasarjana Universitas Padjajaran Fakultas Kedokteran, 2015.

[14] D.B. Kirchner, E. Evenson, R.A. Dobie, P. Rabinowitz, J. Crawford, and R. Kopke, "Occupational noise induced hearing loss," JOEM, vol. 54, pp. 106-108, 2012.

[15] A. Asrun, L.M. Zamrud, and I.P. Sudayasa, Faktor-faktor yang berhubungan dengan kejadian gangguan pendengaran pada karyawan tambang. Kendari: Fakultas Kedokteran Universitas Halu Oleo, 2012 